\title{
Determining the historical significance of the farewell sermon of the Prophet (PBUH) in context of demand of the time
}

\author{
MD. Cholem Ullah \\ Center for University Requirement Courses (CENURC) \\ International Islamic University Chittagong (IIUC), Bangladesh
}

\begin{abstract}
In the $10^{\text {th }}$ Hijrah, the Prophet Muhammad (PBUH) performed Hajj (pilgrimage) only once in his life and delivered his historic 'Farewell Sermon' for the liberation and welfare of the world humanity. This paper explores the importance and significance of the sermon in the context of its historical demand and its place in the world civilisation. The article also attempts to review historically on speaker, time and application of the speech to determine its place in perspective of world history and Islamic history as well. The methodology of the paper followed a qualitative approach comprised of the secondary source. It is argued that the sermon is the only historic speech in the world that incomparable provisions on liberation and welfare of humanity till the Final Day. The ultimate implication of the magnificent sermon is sustained ensuring its time was momentous and eventful; the more appropriate time cannot be estimated. Thus, according to historical analysis, the farewell sermon of the Final Apostle $(\mathrm{PBUH})$ is the demand of time intimately and significantly that relevant to today's life and society.
\end{abstract}

Keywords Farewell sermon, History, Civilisation, Humanity

Paper type Research paper

\section{Introduction}

On the $10^{\text {th }}$ year of Hijrah calendar, the glorious mission of Prophet Muhammad (PBUH: peace and blessings of Allah be upon him) was going to be completed; at the moment the Apostle (PBUH) had decided to go on Haji, and the month of Dhul-Haij was only at hand. Likewise, the Holy Prophet $(\mathrm{PBUH})$ realized that he was soon to bid farewell to his followers. Meanwhile, he (PBUH) was already permitted by Allah swt take his followers on pilgrimage or Haji, and he set on the journey towards Mecca for performing fundamental pillar of Islam hajj. It was the only pilgrimage performed by the Prophet (PBUH) on the last of his prophetic career, because of his extreme business in preaching Islam and teaching all followers Quran and Sunnah.

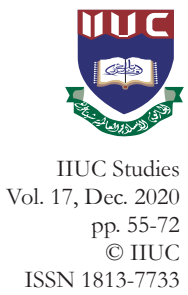


Historically, the farewell sermon of our Prophet Muhammad (PBUH) is not only estimated one of the most significant parts of his missionary life but also remarked as the essential guideline for the humanity. The final Messenger of Islam had ever been a space before the ocean of believers where he delivered his pristine speech, and it was the last sermon of Prophet (PBUH) before a vast mass gathering. This speech is the comprehensive synopsis of all missionary activities of Holy Prophet (PBUH) since 23-years of his prophetic life at Mecca and Medina as well as the speech is a concise summary of all Islamic principles revealed from Allah the Exalted to the last Messenger (PBUH). Hence the sublime sermon is just the basic guideline and fundamental principles for all nations of the world for both temporal and perpetual life till the Day of Final Judgment.

In this article, it was taken an initiative to prove it that the farewell sermon was the demand of time and historically Muslim ummahi along with all other communities felt the urgency of a complete and collective guideline of Islam for all human beings of the world. Amazingly this sermon is only the exclusive one that is theoretically and practically implemented by its speaker in his (PBUH) life as Prophet. So this paper explores the historical importance and significance of the sermon based on contemporary socio-cultural orders all around the world. This radiant sermon is elucidated as the sublime message; a majestic and more contextual sermon in the world has ever been received in the history of civilisation. With the appreciation of all historical records, it can be marked that the address enjoined upon the ummah the important rules for the socio-economic, political and overall life that are essential to human life and society. Because Muslims are selected by Allah the Exalted as the best nation ${ }^{\mathrm{ii}}$ and Deen as Islam has been perfected and approved for ummabiii.

\section{Literature review}

The Prophet (PBUH) set a unique example in the history of world civilization in the establishment of human unity, universal brotherhood and human rights in his last sermon of Farewell Hajj (Haykal, 1976; Rahman, 2016). Rasulullah (PBUH) made his sublime speeches for the ummah on the tenth year of Hijrah in three individual events respectively at the time of performing hajj-on the $9^{\text {th }}$ Dhul-Hijjah at Arafah, at Mina and at Ghadir-i-kbum after his leaving from Mecca (Ali, 1982; Nadwi, 1982; Rahman, 2016; Siddiqi, 1994). The sermon partially comprises the passage of all authentic books of Hadith that were collected from narrators (Sabih al-Bukbari, Sabih al-Muslim, Abu Dawud, Nasai.). Therefore, all sentences of the address were not embodied in a single narration from A to $\mathrm{Z}$.

Likewise, although the farewell speech is mentioned in all the books containing the biography of the Prophet $(\mathrm{PBUH})$, the historical necessity of 
the sermon, its significance and necessity of the demand of time are not discussed much (Ali, 1972; Al-Mubarakpuri, 2015; Hisham, 1995; Hitti, 1970; Najjar, 1983; Salahi, 2002; Salaim, 1427H; Siddiqi, 1994). All biographical books on the Prophet (PBUH) are limited with only the main address of the sermon; but none could give a satisfactory ideas or salient feature about the sermon from the view of historical necessities and importance (Hisham, 1995; Nadwi, 2015; Najjar, 1983; Siddiqi, 1994; Salaim, 1427H.). On the other hand, very concise discussion occupied in the almost books of Prophet's (PBUH) biographical books. Thus, the paper took an initiative with a view to finding out the seminal historical significance of the Farewell Sermon of the Prophet (PBUH) in context of demand of time from historical and biographical literatures.

\section{Methodology}

This study is a desk-based and library-oriented history-based research, it is also qualitative type research. The paper consulted available written literature, key Arabic books on Sirat-al-Nabi or Biography of the Prophet (PBUH), journals and magazines in the field of Islamic history to find out the historical significance of the Farewell Sermon of the Holy Prophet Muhammad (PBUH) in the sense of the demand of time. In this respect, the secondary data has been extracted both from Islamic and historical literature. It is worth noting here that in this review, the Qur'an and Hadith are used as the original and primary source of knowledge for the respective theme and findings. Other related literatures are also carefully researched and reviewed to fulfill the established goal of the present research as evolution the historical significance of the farewell sermon in relation to the demand of the time.

\section{Preparation and set out towards Mecca}

In Islam, Haji (pilgrimage) is one of the five fundamental pillars of Islam. But holy Prophet (PBUH) didn't get chance to perform this obligatory ibadab yet and now Dhul-kadah, and the month of Hajj or Dhul-bijjah of the tenth year of hijri calendar was very close to him (PBUH). Though Last Messenger of Islam Muhammad (PBUH) already completed Umrah two times in his life of Medina, he (PBUH) didn't find a right time to carry out Haji (pilgrimage ritual in full) due to his (PBUH) engagement with state and religious affairs. These entrusted responsibilities were accomplished with extraordinary successful measures and in a complete Islamic environment. Now Prophet Muhammad (PBUH) realised that a brief comprehensive summary of his (PBUH) all duties and responsibilities were needed to present publicly at a suitable meeting. In the meantime, all the nomads Arab embraced Islam, and Islam started to get global form. 
Meanwhile, the distinguished ambassadors of the Prophet (PBUH) conveyed the invitation of Islam to all existing emperors of the surrounding world; Islamic sovereign state was already established and flourished with all functions making Medina as capital. Since the "year of delegations" iv Hajj is ordained in the Quran as farz ibadah (compulsory duty), final Messenger (PBUH) eagerly waited for a convenient opportunity that would favor him (PBUH) leading as well as performing Hajj with all believers. Moreover, it was also the duty of the Prophet (PBUH) to lead the believers to Mecca for performing Hajj, for teaching them practically like all other pillars of Islam (Hisham, 1995: 297). In consequence of such intention, the Muslim community would learn and observe all embargos and total system of Hajj directly from the Final Messenger (PBUH).

So, the Holy Prophet (PBUH) sent representatives to all parts of Arab peninsula for the announcement of his (PBUH) journey to Mecca to participate for perform Hajj. He (PBUH) invited to all Muslims to join him $(\mathrm{PBUH})$ in this greater pilgrimage (Siddiqi, 1994: 297). Responding to the announcement massive numbers of followers, who were more than a hundred thousand, came to Medina. Even many followers' throngs joined the assembly in the way until there were huge numbers than one could mention. The companions of the Prophet (PBUH) entered into Medina. They encamped in and outside of the city where they came the numbers about 100,000 to 114,000 congregations from every nock and corner of the peninsula (Naved, 2009: 176). In which side Prophet (PBUH) extended his eye, he could see devoted believers in every direction. Before setting on journey, he (PBUH) instructed the people how to be prepared for Hajj and taught essential and exclusionary rules of Hajj. He (PBUH) started the journey for Mecca on $25^{\text {th }}$ Dhul-kadah Saturday with 100 animals for sacrifice and caravan followed him and arrived at Mecca on $4^{\text {th }}$ Dhul-hijjab .

\section{The farewell sermon on the day of $9^{\text {th }}$ Dhul-Hijjah (the Day of Arafah)}

Muhammad (PBUH) entered the Sacred Masque (Masjidul Haram) with mass rally and circumambulated the ka'bah, offered two rak'ah prayers at the station of Ibrahim (Asw) that is known to us Maqam Ibrahim, and then he (PBUH) preceded seven circuits between two hills Safa and Marwah. ${ }^{\text {vi }}$ And all of his companions followed him accordingly. After that Holy Apostle (PBUH) remained to stay with the consecrated state of pilgrimage at Mecca until the date of $8^{\text {th }}$ Dhul-Hijjah. (Mubarakpuri, 2002: 298-299); asked the pilgrims those had brought animals for sacrifice to remain in Ibram (consecration) $^{\text {vii }}$ and ordered others to release Ibram. (Salahi, 2002: 783). It was the day of $8^{\text {th }}$ Dhul-Hijjah, when Muhammad (PBUH) left with all followers for Mina with glorifying Allah by Talbiah, reached there at noon and passed the night. 
Next day on $9^{\text {th }}$ Dhul-Hijjah after the sunrise the peaceful possession of pilgrims marched to Arafah where the Prophet (PBUH) delivered the celebrated sermon of farewell Hajj. As the sun was moving down the west, all companions encompassed their Prophet (PBUH), and the Prophet $(\mathrm{PBUH})$ mounted on his camel and rode into the Namirah (the valley of Arafah); all waited eagerly to hear his definitive speech. In the time of the address of Prophet (PBUH), every sentence of the sermon was repeated by Rabiah bin Ummayyah bin Khalf before the assembly.

It is mentionable that the farewell sermon of the Prophet (PBUH) was longer than all other speeches in the prophetic mission. In fact, the address neither was possible to record from a single narration nor collected from only one authentic source. A to $\mathrm{Z}$ accordingly, all sentences of the address was not embodied in a single narration. Even the sermon is intertwined partially comprising the passage of all authentic books of Hadith that were collected from narrators by the methodological way. So, if all narrations related to the sermon will be compiled into a feature, a comprehensive picture of the sermon can be portraited. Furthermore, the noble Apostle (PBUH) made his sublime speeches for the ummah on the tenth year of Hijrah in three individual events respectively at the time of performing hajj-on the $9^{\text {th }}$ Dhul-Hijjah at Arafah; secondly, at Mina on $10^{\text {th }}$ Dbul-Hijjah; thirdly, on $11^{\text {th }}$ or 12th Dhul-Hijjah at Ghadir-i-khum ${ }^{\text {viii }}$ after leaving Mecca. Thus scholars and biographers are intended to sketch out the sermon by collective figures of the compilation of these three addresses of mentioned events. Nonetheless, the address of Arafah is remarked as the central part of the speech of Rasulullab (PBUH) (Salahi, 2002:784). But Siddiqi said that the Holy Prophet (PBUH) also delivered almost same sermon on 2nd time on the occasion of Farewell Hajj (Siddiqi, 1994: 301). ${ }^{\text {ix }}$ According to the narration of Hadith and Biographic documents of our Prophet (PBUH), the comprehensive feature of the Farewell sermon may be mentioned as follows:

-- All praises be to Allah. We glorify Him and seek His help and pardon, and we turn to Him. We take refuge with Allah from the evils of ourselves and the evils consequences of our deeds. There is none to lead him astray whom Allah guides aright, and there is none to guide him aright whom He leads astray. I bear witness that there is no god but Allah alone; having no partner with Him, and I bear witness that Muhammad is His Messenger. I admonish you, O bondmen of Allah! To fear Allah and I urge you to His obedience and I open the speech with that what is good (Salahi, 2002: 298-299).

Ye men! Listen to my speech because I do not think that after this year I shall ever meet you in this place (Hisham, 1995: 297). 
-- O people! Verily your blood, your property and your honor are sacred and inviolable until you appear before your Lord, as this day and this month is sacred for all. ${ }^{x}$ Surely, you will meet your Lord and you will be held answerable for your actions. Beware! Do not become infidels after me, cutting the throats of one another. Have I not conveyed the message? O Allah! Be my witnesses. ${ }^{\mathrm{xi}}$

He who has any trust with him he should restore it to the person who deposited it with him.

Beware no one committing a crime is responsible for it but he himself. Neither the son is responsible for the crime of his father, nor the father is responsible for the crime of his son.

O people! Listen to my words and understand them. You must know that a Muslim is the brother of the Muslim and they from one brotherhood, Nothing of his brother is lawful for a Muslim except what he himself allows willingly. So you should not oppress one another. $O$ Allah! Have I not conveyed the message? (Salaim, 1427H.: 527).

Behold! All practices of paganism and ignorance are now under my feet. The blood-revenges of the days of ignorance are remitted. The first claim on blood I abolish is that of Ibn Rabiab Ibn Harith who was nursed in the tribe of Sa'd and whom the Hdhayl killed. .ii $^{-}$

Usury is forbidden, but you will be entitled to recover your principal. Wrong not and you would not be wronged. Allah has decreed that there should be no usury and I make a beginning by remitting the amount of interest which Abbas b. 'Abd Muttalib has to receive. Verily it is remitted entirely." xiii

-- O people! Verily your Lord is one and your father is one. All of you belong to one ancestry of Adam and Adam was created out of clay. There is no superiority for an Arab over a non-Arab and for a non-Arab over an Arab; nor fro white over the black nor for the black over the white except in piety.' Verily the noblest among you is he who is the most pious" xiv

-- Ye man! The postponement of sacred month is an addition of the days of disbelief. Those who choose disbelief are misguided thereby:

They declare it sacred one year and non-sacred another year. In order to make up the number of sacred months fixed by God, so that they make non-sacred what God has made sacred. Time has completed a cycle and come to the state of the day when Allah created the heavens and the earth. The year is constituted of twelve months, of which four 
are sacred; three of them consecutive, viz. Dhu'l-Qa'da, Dhu'l- Hijja and Muharram, and also Rajab the month which comes between Jumada and Sha'ban. And Time revolves, as it has been shaped since the day the heavens and the earth were created by God. And the number of months with God is twelve of which four are sacred-three consecutive months (Dhul-Khadah, Dhul-Hijjah, Mubarram) and Rajab by itself between Jamadi and Sbaban (Hisham, 1995: 298).

-- O people! Fear Allah concerning women. Verily you have taken them on the security of Allah and have made their persons lawful unto you by words of Allab!! Verily you have got certain rights over your women and your women have certain rights over you. It is incumbent upon them to honour their conjugal rights and, not to commit acts of impropriety and are faithful to you, cloth and feed them suitably. ${ }^{\mathrm{xv}}$

Behold! Lay injunctions upon women but kindly (Hisham, 1995: 298).

O people! Listen and obey though a mangled Abyssinian slave is your amir if he executes [the ordinances of] the Book of Allab among you.

O people! Verily Allah has ordained to every man the share of his inheritance. The child belongs to the marriage-bed and the violator of wedlock shall be stoned. He who attributes his ancestry to other than his father or claims his clientship to other than his masters, the curse of Allah, that of angels, and of the people be upon him. Allab will accept from him neither repentance nor righteousness (Salaim, 1427H.: 527).

And your slaves! See that you feed them with such food as you eat yourselves and clothes that you yourselves wear. And if they commit a fault which you are not inclined to forgive, than part with them for they the servants of Allah and are not to be chastised." xvi

Behold! Listen to me. Worship your Lord; offer prayers five times a day; observe fast in the month of Ramadan; make pilgrimage to the House (ka'bah); pay readily the Zakat (poor due) on your property and obey whatever I command you, only then will you get into the heaven (Najjar, 1983: 388).

Let him that is present convey it unto him who is absent. For happily, many people to whom the message is conveyed may be more mindful of it than the audience. ${ }^{\text {xvii }}$

--O people! Verily the Satan is disappointed at being ever worshipped in this land of yours, but he can be obeyed in anything short of worship 


\section{IIUC Studies, 17}

he will be pleased in matters you may be disposed to think of little account, so beware of him in your matters of religion. (Haykal, 1976) Verily, I have left amongst you the Book of Allah and the Sunnah of His Apostle which if you hold fast, you shall never go astray.

"And if you were asked about me, what would you say?

They replied: "We bear witness that you have conveyed the message, and discharge your ministry." The Prophet said thrice, "O Allah! Be witness for it." ${ }^{\text {xviii }}$

\section{Determining historical place in quest of the significances of the sermon} 6.1. Fulfillment of the mission of the Final Messenger Muhammad (PBUH): Apparently by the conclusion of the farewell sermon, it was also revealed the completion of Islam as complete religion as well as complete code of life. When Holy Prophet (PBUH) alighted from his camel after addressing to the believers, he received following revelation regarding the completion of Islam as religion:

"Today I have perfected your religion for you and completed My blessing on you, and I have approved Islam for your religion." xix

The last Messenger (PBUH) immediately declared the decision from Allah with reciting the verse to all who were present on the event. Thus, farewell sermon remarked the moment of fulfilling the mission of the Prophet (PBUH). Likewise, the declaration about the perfection of Islam from Allah does mean that evidently after fulfillment of mission the physical presence of the Prophet Muhammad (PBUH) on the earth would required be no longer. Furthermore, the time is very soon to have his eternal rest in the heavenly through departed from the cares and actions of worldly life (Siddiqi, 1994: 302-303).

Where he had no more time in his hand, hence the Messenger realized in this momentous event where he got the opportunity to illustrate the concise summary of the vivid picture of Islam addressing the assembly. So he $(\mathrm{PBUH})$ announced collective Islamic law and jurisprudence at a glance and made core obligatory of Deen for the ummah what will be their guidance till the Day of Judgment. Likewise, Rasulullah (PBUH) had highlighted basic ordains and prohibits in Islam to all present followers. The sermon is not only the noble sermon before the most extensive public meeting in the life of Prophet Muhammad (PBUH), but also the prospectus of Islam as eternal provisions for all nations, communities, races, sects and regions across the world up to the Last Day. Therefore, the following lines are relevant to the sermon as "No doubt, no better occasion could have been chosen to proclaim the momentous and happy news of perfection of 
religion. This was the place which had never, in the history of the world, witnessed any temporal fights or bloodshed." (Ali, 1972: 192).

\subsection{Farewell Sermon is the 'Sermon of Message' :}

No other Islamic occasion can amass a massive gathering of believers except Hajj. Since Rasulullah (PBUH) appositely chose the farewell pilgrimage for approaching his message for all mankind before the assembly on the Day of Arafah. So the last Hajj or pilgrimage of the Prophet (PBUH) is called 'The Farewell Pilgrimage', and the pilgrimage is also called 'The Pilgrimage of Message' because the Prophet (PBUH) delivered his message to all mankind and he charged those were present to convey the message to who were absent so that it might be carried out to all succeeding generations and nations over the world (Naved, 2009: 179). Undoubtedly, the Prophet's (PBUH) life, teachings and practices have offered such noble thoughtful spiritual messages to all humankind beyond times' frame of any age and also given real complete portraiture of life that is a task of epic scale (Husain, 1992). In consequence of 'Blessing to all humankind' in Quran for him, the message of the farewell sermon did not address any particular community, nation or country; the sermon was preached to all humanity of the whole universe. The message, therefore, is the eternal and the most important guideline for all humanity till the Day of Resurrection.

\subsection{Farewell Sermon is the Sermon of Annunciation:}

Haykal remarked the Farewell Hajj as the 'Pilgrimage of Annunciation' because the Holy Apostle (PBUH) had completed the announcement of all his duties and works in the sermon of farewell pilgrimage. His conveyance to the people of what he has been commanded by God to announce and to convey. He conveyed accordingly to the people what Allah has revealed to him; indeed, the Final Messenger Muhammad (PBUH) was only an announcer, a conveyer, and a warner who was sent to a people who see the truth and believe (Haykal, 1976: 488). And the substantial and convincing historic announcement was made as to the sermon of the Farewell Pilgrimage. Thus, the pilgrimage of the Prophet (PBUH) can be entitled as the pilgrimage of proclamation due to the farewell address of the last Apostle (PBUH). Here, the speaker proclaimed in the sermon core principles and codes of Islam for all faithful. And he omitted and trampled all the customs of Jahiliyyah such as usury; compensation of bloodshed; announced firmly the Oneness and the glory of Allah the Exalted with upholding the Holy Quran and Sunnah to be remained firmly face against evils; conveying the annunciation for the absentee of the assembly. 
6.4. Importance of Dawah and emphasize on preaching Islam at everywhere of the World:

At the end of the ninth year of Hijrah, and in the last days of tenth year, absolutely not all Arabs embraced Islam from pagan while that time the year of delegation was styled in the career of Rasulullah (PBUH). As the 'mercy to the world' ${ }^{\mathrm{xx}}$ Muhammad (PBUH) employed with all his endeavors and capacities to fulfill his task and duties as the last Messenger of the world, so after him, every Muslim is responsible preaching Islam and carrying the light of Islam to regions far away and save humanity from stark ruin. Of course, this responsibility and duty are Dawah, and this Dawah is a regular task of a believer in Islam. The Prophet (PBUH) intentioned put emphasis on Dawah of Islam in the address of Farewell sermon so that mandatorily ummah will keep continuing spread of Islam as the mission of the Prophet (PBUH). In the speech, he (PBUH) ordered the present audience the message of sermon they must be conveyed to those who were absent. He hoped that the sermon shall be told may remember more than he who has heard it. xxi

Moreover, the final religion in the world is Islam decided by Allah and Allah revealed the Quran on the final Messenger Muhammad (PBUH) to bring out the humanity from darkness to light by their Lord's leave. ${ }^{x i i}$ The advent of the Prophet (PBUH) bestowed all ignorant uncivilized polytheist superstitious humankind by giving a new life, a new faith, a new state, a new society, a new culture and civilisation (Nadwi 1982: 45). But the declaration of the perfection of Islam as religion and the conclusion of the mission of the Final Messenger were notified universally despite it's preceded marked in the Arab region.

Because that time, many races and regions all over the world were still left to know Islam and its message as only perfect religion of the earth. Hence the Hole Prophet (PBUH) delivered the sermon by which ummah radically can offer Islam to any non-Muslim on account of the actual understanding reason why he/she should receive Islam. At the same time, ummah gets all the basic principles of Islam from the sermon; they can be purely the best nation amongst all nations if they follow accordingly the sermon of farewell pilgrimage.

6.5. The Prophet Muhammad (PBUH) the most successful leader in the world: Farewell sermon is the most outstanding speech of the greatest leader in the world forever. This address is the live streaming of the most successful leader and vividly eventful career of the Holy Prophet (PBUH). Besides enduring many sufferings severe hardships many difficulties, according to the guidance of revelation the Leader (PBUH) established a society-free from all evils, gender and other existing discriminations, superstitious, ignorance of Arab's life- and established a sovereign state- comprised of all religious communities 
with ensuring rule of law-and he sustained the equal policy for all subjects of the state. He (PBUH) is only the unparallel leader in the world what he preached to others firstly he practices these himself; only practices alone are the true index of one's real dignity (Husain, 1992: Preface-viii).

Before ending his journey, the charismatic human Leader (PBUH) just presented the summary of his all actions, reforms and duties through the farewell sermon. S. Athar Husain symbolized the life of the Prophet (PBUH) as: "His life was so dynamic, so packed with thrilling and consequential events that it caused an upheaval in the religious, cultural, social, political and economic life." (Husain, 1992: 119). So this sermon does not only comprise the fundamental principles of the mission of Muhammad (PBUH) but also the successful conclusion of his strenuous life-time.

\subsection{Convocation of Believers at Arafah:}

By the tenth year of Hijrah, Islam had prevailed over all regions of Arab. A great number of qualified manpower as dayee (Preachers of Islam) - followers of the Holy Prophet (PBUH) accomplished their missionary training by their Prophet $(\mathrm{PBUH})$ - were prepared of carrying out the banner of Islam throughout the world. And these disciples before now arouse in the peninsula in the coming years. All of the preachers as and now they were ready to receive final action plans through a public conference. That qualified believers were needed to be instructed finally by arranging a program. And obviously, the Farewell Sermon is like convocation of believers at the premises of Arafah, where the pristine sermon of Prophet (PBUH) was the final guideline for Islamic missionary activists to uphold Islam globally as the complete religion amongst all religions and doctrines. The sermon was also a successful felicitation ceremony of only just completed training of believers in the period of the prophetic tenure of the Holy Apostle (PBUH). By this assembly, Allah the Exalted chose to show the success of his 23-years mission of His beloved Messenger by calling him to have a farewell pilgrimage (Mubarakpuri, 2002: 298). "Their convocation was an inspiring evidence of the victory of truth, of the wide reach of the light of God, and of the deep bond of truth and righteousness which had cemented them one to the other so that they stood like one great fortress." (Haykal, 1976: 483).

6.7. Taking oath from all Believers for following the teaching of the Prophet (PBUH): One of the reasons arranging the assembly at Farewell Hajj was taking oath from all faithful about abiding the teachings and principles of their Prophet (PBUH). After having been commissioned as the Final Prophet, the Holy Apostle (PBUH) started his mission aiming at declaring the Oneness of Allah and the unity of all humanity; he was blessed as the mercy to world. Emancipating from ignorance and disbelief, he led mankind to the light of 
faith and celestial happiness (Husain, 1992: 9). With providing the teaching and training for the performing Hajj in last farewell pilgrimage, he organised the meeting of all believers to advice them about Islam for the last time, make to commit them following his teaching after him. So for having these intentions of the Apostle (PBUH), he would conduct an oath fastening on all Muslims to abide his life and teachings and to be rid of the last traces of the age of ignorance (Nadwi, 2015: 173).

In the three events of the farewell sermon, similarly, at the end of his address, the Apostle (PBUH) used to ask the entire congregation that when Allah would ask them about conveying his message on the Day of Judgment, so what answer they would give to Allah. All present followers replied as one voice that they would bear testimony that he had (PBUH) conveyed the message and fulfilled perfectly his mission. Raising then Prophet's hand towards the sky he addressed Allah thrice, "Oh Allah, be witness"! (Ali, 1982: 377-383). By this way he took an oath from the all members of the assembly and all audience also vowed on the words of their Holy Apostle (PBUH) that they do carry out and execute the responsibilities of the Rasulullab (PBUH) in his absence. On the other hand, Allah the Exalted wished that His Prophet (PBUH) took exact testimony of all present faithful that on the other hand, Allah the Exalted wanted that His Prophet (PBUH) would receive exact testimony of all present faithful that he had delivered the Message and guided mankind and purified the people. (Mubarakpuri, 2002: 236). Hameed Siddiqi commented on the oath as "He had delivered the message which sums up beautifully the fundamentals of Islam and the responsibilities which all upon the shoulders of Muslims as standard-bearers of the Divine-faith." (Siddiqi, 1994: 303).

6.8. The sermon proved Muhammad (PBUH) as the Final Messenger and Prophet:

Immediately after the farewell sermon, the declaration of the perfection of Islam proved the necessities of next apostle was fully over. Even the Final Apostle (PBUH) firmly announced addressing all humankind 'there is no new prophet after me, and even no nation or ummah will be after you.' xxiii Then he (PBUH) firmly urged all his followers to worship the only Lord Allah, to observe five times prayers, to fast in Ramadhan, to pay Zakah (poor-due) willingly, to perform Hajj to the sacred House of Allah, to obey those are in authority among them. If believers follow these instructions, Allah will give them Paradise as an award (Mubarakpuri, 2002: 237). Since Allah already decides Muhammad (PBUH) is the final and last Prophet till the Day of Resurrection in the Quran, he affirmed the decision of his Lord in the farewell sermon before the hosts of huge numbers of devoted monotheists. By uttering the decision about final Messenger and Prophet, he 
decreed the basic provisions of Islam upon the Muslims. Of course, Allah sent His Messenger $(\mathrm{PBUH})$ to preach and establish that basic parts of Islam. So, indeed, there will be no new prophet, the prophet mission will be conveyed by his followers or Muslim ummah till the Final Day of Judgment.

6.9. The sermon is the world's most incredible speech ever:

Amazingly, in the sermon, a brief restatement of the all Islamic principles was pronounced like putting of many types of scenery to one frame. The sermon is better than a thousand addresses and lessons (Ali, 1982: 373). In the whole missionary life of the Prophet (PBUH), the farewell sermon was the most prolonged lectures but lasted only minutes. He completed his address in a state of deep and wide attention of the audiences so that they wouldn't feel any kind of losing the patience or fatigue. How many indispensable and supplement components are required for a breathtaking speech, all the elements are vividly reflected in the sermon of the Apostle Muhammad (PBUH). Throughout the question-and-answer process in the sermon, between the speaker and the listener made an excellent communication with understanding. It is an excellent record that is so authentic, so detailed, and there has never existed a document of historical relevance that can be compared to any European itinerary or of the memory of any great saint or scholar (Ali, 1982: 374).

The address is not only incredible for its eloquence but also its glorious and sublime message to humankind on the earth. No better principles have been set in any other speech in the world than the Farewell sermon on ethics. What an enchanting and attractive sermon is the farewell address! Every sentence breathes a sense of greatness and establishes righteous and fair dealing among humanity on a workable basis. This sermon consolidates the unity of ummah, establishes all types of Muslims of the world into one brotherhood, It touches the end by determining a social system that is completely free from all forms of exploitation and injustice (Siddiqi, 1994: 303). In the context of knitting such artistic slides, it can be said the farewell sermon of Prophet Muhammad (PBUH) holds its position as the world's most incredible speech forever.

Very clear-cut and brief speech, displaying confidence in voice, common transition of phrases like "oh mankind hey people". A brief restatement of the focal points of Islamic ethos was incorporated in the sermon, effective conclusion with taking oath from the present faithful assigning duties of Prophet (PBUH).

\section{Conclusion}

In fact, on the occasion of farewell Hajj, the magnificent farewell sermon of the Holy Apostle (PBUH) is indeed an unforgettable and the most majestic 
address that is unprecedented in the history of world civilisation. The appeal of this heart-touching sermon is everlasting. Addressing the colossal mass gathering of the believers at the farewell pilgrimage, the Holy Prophet (PBUH) advised them on Islamic laws, rules-regulations, ideologies and principles those were enjoined since 23-years of the Prophetic missionary life of Muhammad (PBUH). In the discourse of complete address, the Prophet (PBUH) took a pledge from all faithful on account of following the principles of Islam accordingly, and all present companions being committed to Allah and His Prophet (PBUH), they pledged to abide all rules and regulations indicated in the speech.

If the Apostle (PBUH) hadn't intended to host a vast multitude of his companions, he wouldn't have invited his all followers for pilgrimage. In fact, when it was passing the last half of 10th year of Hijrah, the Messenger of Allah (PBUH) visualized about completion of his mission, and it also implied his departure from the earthly life to the heavenly abode. Since he (PBUH) will not be longer, a permanent guideline is surely needed for his disciples having focused Islam as completed and perfected code of life everywhere globally. For mitigation of the urgent needs, the Apostle (PBUH) made a public announcement for Haji, verily the swarming crowd of believers around the stage for addressing of the Final Messenger (PBUH) had been prepared in the events of farewell Haij at Arafah. Eagerly awaited and enthusiastic all Muslims understood that the Prophet (PBUH) would deliver radiant sublime address to them.

Hence, it can be appreciated as the final triumph of truth, because after receiving spiritual lessons from the sermon ummah was keenly disseminated for preaching Islam around the world. And from the sublime spiritual sermon of farewell pilgrimage the globalization of Islam and from the same time its civilisational development started to bring the regeneration of all global orders. (Rahman, 2016).

\section{Recommendations}

1. Rasulullah's (PBUH) farewell speech not only binds all Muslims to a strong bond of brotherhood, but also ensures all kinds of security, including the safety of life, dignity and property of all. Nothing was remained to provide in the sermon those are relevant to the life and society of every modern state, either western or eastern world. Holy Apostle (PBUH) provisioned as a final point of the essentials of human life- Declaration of universal Human rights, removing all kinds of racism, being trampled all ignorance of jabiliayyah, removing bloodshed and riba- his Farewell Sermon.

2. Although all basic needs and human rights were declared in the sermon 
regarded women, slaves, social security, orphan, life and property, offenders, inheritance, practice of religion, dignity for each other, economic safety etc. were guaranteed in the life and society practically; the Apostle (PBUH) enkindled all present believers by re-expressing these rights in the last sermon of his life.

3. Responding to the announcement of the Prophet (PBUH) a large spontaneous believer gathered to perform Hajj. And this huge righteous felt the special need of an encouraging and instructive speech from the farewell pilgrimage of their Holy Prophet (PBUH) that the speech would guide them till the last Day of Judgment. On the contrary, in the case of other world-renowned leaders, it is seen that historically at a vital moment, the leader delivers a meaningful and significant speech to his nation as a path to international consolidation and development; this is no exception in respect of Rasulullah (PBUH).

4. The holy Prophet (PBUH) reminded the present gathering that they must be accountable to Allah for what they have done in the worldly life; and he emphasized everyone to follow perfectly the path shown by him. In the address, all believers were warned that no one could save them from going astray unless they adhered to the Qur'an and the Sunnah. So the necessities and the historical importance of the sermon for ummab is undeniable, particularly the sermon always urges believers to build a society based on justice free from exploitation and discrimination, irrespective of class, caste and religion.

5. It is also observed that all basic laws, religious provisions, spiritual matters, rules and regulations of Islam were not elaborately mentioned in the tone of the farewell sermon. Still, what kind of provisions and guides have been spelled out, definitely are vital to lead the life and society of a faithful in this worldly abode. Moreover, the most important principles and provisions of Islam were declared in the sermon; those are the best action plans and the most significant policies in order to establish the most attractive welfare society and state in the world; and these principles were followed properly in the Medina state and the state of the rightly-guided Khalifab in Islam.

6. Though the instructions of the sermon are basically directed to the believers, these are equally applicable for every country and nation in the world; because these principles can make any country or nation a peaceful and prosperous nation based on unity, equality and brotherhood. Thus farewell sermon is eternal and universal- given by the last Prophet - still calls on all humanity today to build peaceful law and order, social security, sustainable and justified human rights, a better life and a better society.

7. The sermon has such radiant and noble messages to humanity to a new pattern of life, that comprehensive portraiture is a task of immense 


\section{IIUC Studies, 17}

magnitude. Likewise, the sermon simultaneously encourages and warns the Muslim ummah for upholding Islamic traditions and all human rights based on Qur'an and Sunnah as well. The importance and appeal of this discourse in the eyes of history are immeasurable forever.

\section{Notes}

i. Arabic word 'ummah' means "community" or "nation". In the context of Islam, it is used to represent the diasporas or "community of believers" and thus the whole Muslim world. (For details http://islamic-dictionary.tumblr.com). The word ummah is used for people of Islamic Community having emotional, moral, social ties that are stabilised with the personal relationships as well as continuation over time. In recent times, the concept of the ummah is achieving a global nature as Islam is a global community.

ii. Al-Quran, Surah Al-Imran:110.

iii. Al-Quran, Surah Al-Ma'idah:03.

iv. In $9^{\text {th }}$ Hijri calendar delegations flocked from near and far of Arab Peninsula to offer loyalty to Islam on hand of Prophet (PBUH). Various tribes and Bedouins joined out of either convenience or not conviction from heart, and they all embraced Islam with exacting a verbal profession of belief in Allah the Exalted and His Final Messenger (PBUH); and confessed to paying zakah (poor tax) (Hitti, 1970: 119).

v. Hadith. Sahih al-Bukhari, Abu Abdullah Muhammad ibn Ismail, Kitab al-Hajj (Book of Pilgrimage), Bab: Wujubu al-Hajj wa-Fadlibi (Chapter: What kind of clothes a Muhrim should wear), Hadith \# 1545; (Book.25, \#31).

vi. Hadith. Sahih al-Bukhari, Abu Abdulah Muhammad ibn Ismail, Kitab al-Hajj (Book of Pilgrimage), Bab: Wujubu al-Hajj wa-Fadlihi (Chapter: 'Two Rak'a prayer after Tawaf), Hadith \# 1623, 1624; ( Book.25, \#108).

vii. Prophet $(\mathrm{PBUH})$ asked the pilgrims who hadn't brought sacrificial animals along with them to release Ihram and allowed them to shave their heads and remained the state till they stayed in Mecca. When Holy apostle left Mecca and started towards Mina, the pilgrims of shaved heads were ordered to assume Ihram again until the time of pilgrimage was over (Mubarakpuri, 2002:.298-299).

viii. In the history of Islam, Ghadir Khumm is well known as the place where Holy Prophet Muhammad (PBUH) delivered a significant sermon during his return journey from the farewell pilgrimage on the $18^{\text {th }}$ Dhu'l Hijja in the midst of a prominent gathering and was also famous as the Prophet's Farewell Sermon (PBUH).

ix. Abdul Hamid Siddiqi remarked that Prophet Muhammad (PBUH) addressed the pilgrims again on $2^{\text {nd }}$ time on Friday (day after Arafah), $10^{\text {th }}$ Dhul-Hijjah and besides from previous speech, he added some important points. The statement is one of the points. (Siddiqi, 1994: 300).

x. Hadith. Sahih al-Bukhari, Abu Abdullah Muhammad ibn Ismail, Kitab al-Ilm (Book of Knowledge), Bab: Qawol al-Nabi Sallallahu Aliabi wa Sallam 'Rubba Muballagiao A'ai 
min Sami'I (Chapter: The Statement of the Prophet (PBUH): It is probable that a person who receives a piece of information indirectly may comprehend it better than he who has heard it directly from its source), Hadith \# 67; (Book.3, \#9).

xi. Hadith. Sahih al-Bukhari, Abu Abdullah Muhammad ibn Ismail, Kitab al-Maghaazi (Military Expeditions led by the Prophet (PBUH), Bab: Hajjat Al-Biidai (Chapter: Hajjat-ul-Wada), Hadith \# 4406; (Book.64, N. 428).

xii. Hadith. Sahih al-Muslim, Muslim ibn al-Hajjaj, Kitab al-Hajj (Book of Pilgrimage), Bab: Hajjat al-Nabbiyyi Sallallahu Aliabi Wa Sallam (Chapter: The Hajj of the Prophet saws), Hadith\#1218a; (Book 15, Hadith 159).

xiii. Hadith. Sahih al-Muslim, Muslim ibn al-Hajjaj, Kitab al-Hajj (Book of Pilgrimage), Bab: Hajjat al-Nabbiyyi Sallallabu Aliabi Wa Sallam (Chapter: The Hajj of the Prophet saws), Hadith\#1218a; (Book 15, Hadith 159).

xiv. Abdul Hamid Siddiqi remarked that Prophet Muhammad (PBUH) addressed the pilgrims again on $2^{\text {nd }}$ time on Friday (the day after Arafah), $10^{\text {th }}$ Dhul-Hijjah and besides from previous speech, he added some important points. This statement is one of the points. (Siddiqi, 1994: 301)

xv. Hadith. Sahih al-Muslim, Muslim ibn al-Hajjaj, Kitab al-Haij (Book of Pilgrimage), Bab: Hajjat al-Nabbiyyi Sallallabu Aliabi Wa Sallam (Chapter: The Hajj of the Prophet saws), Hadith\#1218a; (Book 15, Hadith 159).

xvi. Hadith. Sahih ibn Hibban, Bitartib ibn Balban, Kitab al-Salah, Bab al-waeed ala Tarki al-Salab; Juz.4\#1457

xvii. Hadith. Sahih al-Bukhari, Abu Abdullah Muhammad ibn Ismail, Kitab al-Ilm (Book of Knowledge), Bab: Qawol al-Nabi Sallallabu Aliabiwa Sallam "Rubba Muballagiao A'ai min Sam i'I" (Chapter: The Statement of the Prophet (PBUH): it is probable that a person who receives a piece of information indirectly may comprehend it better than he who has heard it directly from its source), Hadith \# 67; (Book.3, \#9).

xviii. Hadith. Sahih al-Bukhari, Abu Abdullah Muhammad ibn Ismail, Kitab al-Maghaazi (Military Expeditions led by the Prophet (PBUH), Bab: Hajjat Al-Biidai (Chapter: Hajjat-ul-Wada) Hadith \# 4402, 4403; (Book.64, N. 425).

xix. Al-Quran, Surah Al-Maidah:3 (5:3)

xx. Al-Quran, Surah AlAnbiya:107 (21:107)

xxi. Sabih Bukbari, Muslim, Abu Dawnd, Nasai.

xxii. Al-Quran, Surab Ibrabim:1 (14:1)

xxiii. Sabih Muslim, Huzzatun Nabi, p-397.

\section{References}

Ali, M. M. (1972). Muhammad The Prophet (4 $4^{\text {th }}$ ed.). Lahore, Panjab, Pakistan: Ahmadyyah Anjuman Isha'at Islam.

Ali, S. A. (1982). Muhammad Rasulullab The Apostle of Mercy (2 ${ }^{\text {nd }}$ (English) ed.). 
(M. Ahmad, Trans.) Lucknow, UP, India: Academy of Islamic Research and Publications.

Al-Mubarakpuri, S. A. (2015). Al-Raheeq Al-Makhtum (The Sealed Nector). (T. Vista, Ed.) Retrieved 17 April 2020, from https:/ /islamfuture.files.wordpress.com/2014/07/ar-raheeq-al-makhtu m-e28093-the-sealed-nectar.pdf:

Haykal, M. H. (1976). The Life of Muhammad ( $8^{\text {th }}$ ed. 2015). (I. R. al-Faruqi, Trans.) American Trust Publication.

Hisham, M. A. M. (1995). Sirat al-Nabubiah Sallalhu Aliabi Wa-Sallam $\left(1^{\text {st }}\right.$ ed., Vol. 4). (S. F. Majdi, Ed.) Bitanta, Egypt, Egypt: Dar al-Sahabah.

Hitti, P. K. (1970). History of the Arabs (10 ${ }^{\text {th }}$ ed.). London, UK: Macmillan Publishers.

Husain, S. A. (1992). Prophet Mohammad and His Mission. (H. Kabir, Trans.) Lucknow, UP, India: Academy of Islamic Research and Publications.

Mubarakpuri, S. R. (2002). When The Moon Split (A Biography of Prophet Muhammad Sm.) (2nd ed.). (M. R. Tabassum Siraj, Ed., \& M. R. Tabassum Siraj, Trans.). KSA, UK: Darussalam.

Nadwi, A. H. (1982). Islam and The World (7th English ed.). (D. M. Kidwal, Trans.) Lucknow, UP, India: Academy of Islamic Research \& Publications.

Nadwi, S. A. (2015). Muhammad (PBUH) The Last Prophet A Model For All Time ( ${ }^{\text {th }}$ ed.). (I. A. Azmi, Trans.) Lucknow, UP, India: Academy of Islamic Research and Publitions, Nadwatul Ulama.

Najjar, M. A. (1983). Al Qawl Al-Mubin Fi al-Sirat Sirat al-Sayyid al-Mursalin (Vol. 1). Bairut, Libanun: Dar al-Nadwah al-Zadidah.

Naved, D. M. (2009). Encyclopaedia of Islamic Empires And Dynasties (1 ${ }^{\text {st }} \mathrm{ed}$., Vol. 2). (D. M. Syed, Ed.) New Delhi, India: Anmol Publications Pvt. Ltd.

Rahman, D. M. (2016). Beday Hazzer Bhashone Manobadhikar (Human Rights in the Fairwell Haij Address) (Vol. 1). Dhaka, Bangladesh: Islamic Foundation Bangladesh.

Salahi, A. (2002). Muhammad Man and Prophet (1 ${ }^{\text {st }}$ ed.). Leicestershire, United Kingdom: The Islamic Foundation Markfield Conference Centre.

Salaim, A. S. (1427 H.). Al-Sirat al-Nabubiyat Ala Du'il Qur'an wal al-Sunnah (8 $8^{\text {th }}$ ed., Vol. 2). Damascus, Syria: Darul Qalam.

Siddiqi, A. H. (1994). The Life of Mubammad. Delhi: Adam Publishers \& Distributiors.

\section{Corresponding author}

MD. Cholem Ullah can be contacted at: forhad314@iiuc.ac.bd 